\title{
Editorial: Two Meanings of Collaboration in Education
}

\author{
Ian Winchester
}

Published online: 16 May 2014

(C) Springer Science+Business Media Dordrecht 2014

Collaboration is one of the educational buzzwords of our time. It usually means to work together, often in joint intellectual effort.

But there is another meaning, made particularly famous by the Norwegian Nazicollaborator, Vidkun Quisling, during the Second World War-namely, to cooperate reasonably with an enemy force occupying one's country. Thus a quisling is a person who collaborated with the Axis forces in occupied countries during that war. Today, we typically use the word to mean traitor.

Of course, when one agrees on shared goals and when, at the same time, one has intellectual powers, knowledge, or skills that others could use in that joint effort, then collaboration in the former sense is a good thing.

The difficulty in everyday life is that collaboration is often mandated, even when there is no consensus about goals. Governments often require collaboration among their client organizations, without first asking whether this is wise, desirable, or necessary. Those who go along with the mandated collaboration in this context are in some danger of being-in a smaller sphere-quislings too.

In many school boards, the principals and teachers of each school are being asked by their boards or by their state, provincial, or national governments to engage in collaborative approaches to handling all the tasks and problems of a school. Sometimes these approaches apply to each school independently, and put the emphasis on curriculum. That is clearly a realm in which teachers, as a rule, feel comfortable working together.

Sometimes they involve much broader matters of interest or concern: for example, questions about teacher workload. And sometimes multiple schools are asked to collaborate with one another. Of course, where the schools are large enough, there have always been joint efforts on the parts of teachers and principals. But generally, schools were left to their own devices without directives from outside. Today,

\footnotetext{
I. Winchester $(\bowtie)$

University of Calgary, Calgary, Canada

e-mail: winchest@ucalgary.ca
} 
however, governments are beginning to think that they know best, that their expertise is greater than that of individual teachers and administrators in schools or on school boards, and that they are therefore empowered to direct the complex of schools and boards to work together collaboratively.

Collaboration is a buzzword in health care as well. It is generally supposed that if we could work collaboratively, we would work better in health care-especially in hospital settings where physicians, surgeons, psychiatrists, nurses, physiotherapists, radiologists, psychologists, and a host of others must assist in the care of individual patients. Thus it has become quite a common practice to establish collaborative committees that work together to aid in the healing, recovery, and perhaps rehabilitation of individual patients.

In hospitals, a difficulty common to this approach is that collaboration often entails going along with the physician in the committee. Disagreeing with the physician is a difficult business, because in hospital settings the doctor's signature is often final on all matters of patient care. Today, one encounters this attitude most strikingly when one enters a hospital for an emergency. One does not see the physician-the doctor-first. Instead, one sees a triage nurse whose power is restricted to determining whether one will ultimately be accommodated in emergency or sent elsewhere. After many steps and much waiting, often over a 24 hour period, one may finally see a physician with the power to ask for such things as blood tests and to send one to a ward where one might be treated. Everything that happened earlier was only a prelude to the physician's diagnosis and decision. (Interestingly, this strikingly contrasts with the practices of a Chinese hospital, where there are a number of lineups (or snakes) of patients who arrive, finally, at a physician considered to be among the best diagnosticians in the hospital. Then the physician sends the patient onward. The snake is long, but the medical activities afterward are decisive and require no further waiting.)

The attitude in our own hospitals about the primacy of the physician is hard to criticize because often physicians have had much broader and more extensive medical education and experience than anybody else working there. (Though I recall that when I myself interviewed patients as a young medical student, the professor leading us recommended that we ask the duty nurse, if we really wanted to find out what was ailing a patient.)

In schools, of course, collaborative committees often involve teachers and the principal. One wonders whether collaboration in this context does not imply-as it does in medical committees-simply agreeing with the principal.

In today's faculties of education, collaboration may well entail agreeing with the dean, of course. Deans have the peculiarity of controlling their local faculty budgets; all committees report to the dean with their recommendations. Deans do not have to agree with those recommendations; often they do not. They are frequently ex officio members of all committees. Typically, when they actually sit on them instead of having named a designate, they serve as ex officio chairs and so they are empowered to set the agendas for those committees as well.

During my own time as a dean, I consciously tried to resist collaboration that simply entailed agreeing with me, but I think it nevertheless often worked out that way. I remember having lunch with a committee member acting on behalf of a collaborative group I had established to overhaul our teacher preparation program. 
The only thought I had about the matter was that our present program was not well regarded provincially, and that we therefore needed something new and different that would make us stand out both provincially and nationally.

My model was McMaster Medical School, with which I had worked when I had been at the University of Toronto. Founding Dean John Evans had established the school on the principle of overturning the model of medical education that had become standard after the Flexner Report of 1910. According to the Flexner model, after completing either an undergraduate degree in the sciences or a two-year premedical program, students were to undertake a four-year medical program, devoting the first 2 years to broad medical knowledge such as anatomy, physiology, and the fundamentals of disease, and the following 2 years to a more detailed understanding of disease. Finally, after at least 6 years of study, graduates were to undertake a year of clinical practice, during which they worked in a hospital, seeing patients for the first time. Licensure then followed an examination.

On Dean Evans' urging, the McMaster model ensured, by contrast, that students saw patients much earlier, while they were studying. The entire curriculum was comprised of problem- or practice-based learning, in which students saw patients presenting with particular symptoms and then studied the disease processes, anatomy, physiology, and all of the medical knowledge related to the patient's condition. What I had in mind for the faculty of education was something parallel to this program - though quite how to bring it into being, I had no idea.

When my collaborating committee member suggested that the group go to Harvard Medical School (which had copied McMaster), I sent them to McMaster instead. They came back and created a program that for the next 15 years directed the faculty's preparation of teachers, and led to an emphasis on inquiry-based learning in Alberta schools. During this period, Alberta schools moved up to the top of the international charts in terms of student success in the international comparisons in science, mathematics and language ranking us with Finland and South Korea at the top and well above the rest of North America. But was this collaboration? Or was it doing what the dean wanted?

My sense is that the new program was a shock to some members of the teaching faculties, who had hitherto always been free to lecture on their special interests to large groups of students, but were now expected to use inquiry-, problem- or practice-based methods to teach groups of 15 students per class. Some of them must have felt that they were consenting to an occupying force in their midst - that they were enemy collaborators, quislings.

One suspects that the two senses of the term collaboration are nearly always tied to one another. Some will feel that they are willingly working towards a common goal. But others, with equal honesty and strength of feeling, will likely feel like traitors. Sometimes our leaders know best. Sometimes they do not. Sometimes our governments have gotten it right. Sometimes they have not. Vidkun Quisling was labeled a traitor and hung. But we who are engaged in large collaborative enterprises that tend to transform everything are likely to make some feel like traitors. We have to treat them gently, for there are no guarantees that our new educational ventures will prove better than the methods we relinquish. Happily, our collaborative efforts sometimes really are improvements. 